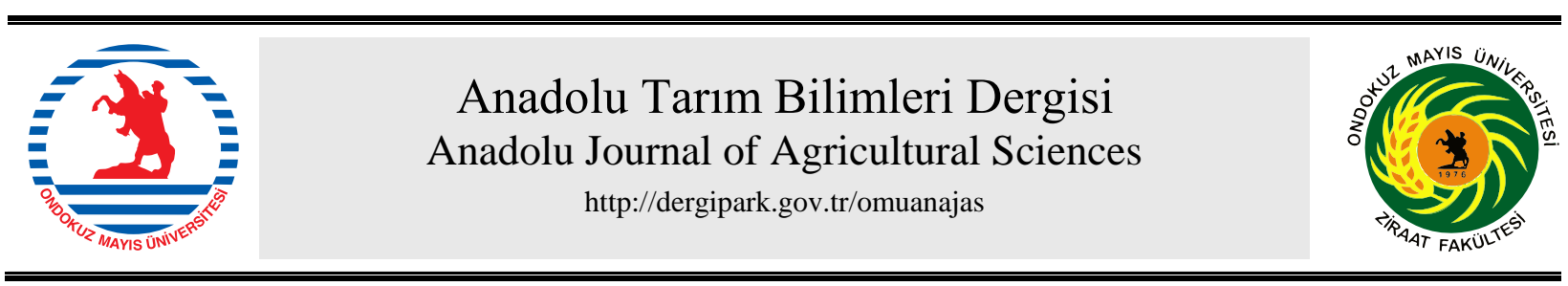

Araştırma/Research

Anadolu Tarım Bilim. Derg./Anadolu J Agr Sci, 36 (2021) ISSN: 1308-8750 (Print) 1308-8769 (Online) doi: 10.7161/omuanajas.845337

\title{
Farklı yulaf (Avena sativa L.) genotiplerinin destek sulamalı ve sulamasız koşullarda bazı kalite özelliklerinin değerlendirilmesi
}

\author{
๑Zeki Mut ${ }^{\mathrm{a}}$, Necibe Demirtaş ${ }^{\mathrm{b}}, \odot$ Özge Doğanay Erbaş Köse $\mathrm{a}^{\mathrm{a}^{*}}$ \\ ${ }^{a}$ Bilecik Şeyh Edebali Üniversitesi, Ziraat ve Doğa Bilimleri Fakültesi, Tarla Bitkileri Bölümü, Bilecik, Türkiye \\ ${ }^{b}$ Amasya İl Tarım ve Orman Müdürlügü, Amasya, Türkiye
}

*Sorumlu yazar/corresponding author: ozgedoganay.erbas@bilecik.edu.tr

Geliş/Received 22/11/2020 Kabul/Accepted 28/04/2021

\begin{abstract}
ÖZET
Yulaf nişasta, protein, diyet lif, yağ asitleri ve $\beta$-glukan gibi besin maddeleri açısından zengin olduğundan hem insanlar hem de hayvanlar için önemli bir temel besin kaynağı olarak kullanılmaktadır. $\mathrm{Bu}$ çalışma, 22 yulaf genotipinin bazı kalite özelliklerinin, yağışa dayalı ve destek sulamalı koşullarda incelenmesi amaciyla 2016-2017 yetiştirme sezonunda Yozgat'ın Yerköy ilçesinde yürütülmüştür. Denemeler üç tekrarlamalı olarak tesadüf blokları deneme desenine göre kurulmuştur. Araştırmada genotiplerin nişasta, protein, $\beta$-glukan, yağ ve yağ asitleri oranları ile asit deterjanda çözünmeyen lif (ADF) ve nötr deterjanda çözünmeyen lif (NDF) değerleri incelenmiştir. Yağışa dayalı koşullarda genotiplerin nişasta oranı $\% 37.1-47.6$, protein oranı $\% 12.7-15.2, \beta$-glukan oranı $\% 3.53-4.58$, yağ içeriğinin \%4.64-7.89, linoleik asit içeriğinin \% 28.8-37.2, oleik asit içeriğinin \% 37.1-47.1, palmitik asit içeriğinin \% 21.7-23.5, stearik asit içeriğinin \% 1.74-2.05, ADF değerinin \%11.9-16.9 ve NDF değerinin \%30.1-37.1 arasında değiştiği belirlenmiştir. Destek sulamalı koşullarda ise genotiplerin nişasta oranı $\% 39.4-49.0$, protein oranı $\% 12.3-14.6$, $\beta$-glukan oranı $\% 3.44-4.06$, yağ içeriği $\%$ 4.878.27, linoleik asit içeriği \% 29.0-37.1, oleik asit içeriği \% 36.3-46.5, palmitik asit içeriği \% 22.7-24.8, stearik asit içeriği \% 1.86-2.05, ADF değeri \% 12.0-16.3 ve NDF değeri \% 30.3-37.5 arasında değiş̧miştir. Yağış̧a dayalı koşullarda G3, G6, G8, G9 ve G15 numaralı genotipler, destek sulamalı koşullarda G3, G8, G9, G11, G13 ve G15 numaralı genotipler nişasta, protein ve $\beta$-glukan içeriği bakımından ortalamanın üstünde değerlere sahip olurken, ADF ve NDF içeriği bakımından ortalamanın altında değerlere sahip olmuşlardır.
\end{abstract}

Evaluation of Some Quality Traits of Different Oat (Avena sativa L.) Genotypes under Supplemented Irrigation and Without Irrigation

\section{ABSTRACT}

Oat is use as an important source of essential nutrients for both humans and animals because of it is rich in nutrition composition like starch, protein, dietary fiber, fatty acid and $\beta$-glucan etc. This study was conducted to determine some quality traits of 22 oat genotypes in rainfall and supplemented irrigation conditions during 2016-2017 growing season at Yerköy/Yozgat. Experiments were carried out in randomized complete block design with three replications. In the trials, starch, protein, $\beta$-glucan, fat, fatty acid ratios, acid detergent fiber (ADF) and neutral detergent fiber (NDF) values were investigated. In experiment without irrigation, among the genotypes, starch ratio varied from 37.1 to $47.6 \%$, protein ratio from 12.7 to $15.2 \%$, $\beta$-glucan content from 3.53 to $4.58 \%$, fat ratio from 4.64 to $7.89 \%$, linoleic acid content from 28.8 to $37.2 \%$, olaic acid content from 37.1 to $47.1 \%$, palmitic acid content from 21.7 to $23.5 \%$, stearic acid content from 1.74 to $2.05 \%$, ADF content from 11.9 to $16.9 \%$ and NDF content from 30.1 to $37.1 \%$. In the trial irrigated with supplemented irrigation, among the genotypes, starch ratio varied from 39.4 to $49.0 \%$, protein ratio 12.3 to $14.6 \%$, $\beta$-glucan content from 3.44 to $4.06 \%$, fat ratio from 4.87 to $8.27 \%$, linoleic acid content from 29.0 to $37.1 \%$, oleic acid content from 36.3 to
Anahtar Sözcükler:

Yulaf

Sulama

Kalite

Protein

$\beta$-glukan 
46.5\%, palmitic acid content from 22.7 to $24.8 \%$, stearic acid content from 1.86 to $2.05 \%$, ADF content from 12.0 to $16.3 \%$ and NDF content from 30.3 to 37.5\%. Genotypes G3, G6, G8, G9 and G15 under rainfall conditions, genotypes G3, G8, G9, G11, G13 and G15 under supplemented irrigation had higher than average values in terms of starch, protein and $\beta$-glucan values while they had below average values in terms of $\mathrm{ADF}$ and $\mathrm{NDF}$.

\section{Giriș}

Her yıl Dünya'da 23 milyon ton Türkiye'de ise 265 bin ton yulaf (Avena sativa L.) tane ürünü elde edilmektedir. Türkiye 2.42 ton ha ${ }^{-1}$ verimi ile dünya ortalamasının üstünde yulaf verimine (2.34 ton ha $\left.{ }^{-1}\right)$ sahiptir. Yulaf hem Dünya'da hem de Türkiye'de tahıl üretimi içinde 6. sırada yer almaktadır (FAO, 2018). Diğer tahıl mahsulleri ile karşılaştırıldığında yulaf, düşük verimli topraklar dahil olmak üzere marjinal alanlarda üretime daha uygun olan düşük girdili bir tahıldır (Hoffmann, 1995).

Besin içeriği diğer bütün tahıl türlerinden yüksek olan yulaf tanesi (Rauf ve ark., 2019), protein, $\beta$-glukan, karbonhidrat, yağ, yağ asitleri, vitaminler, mineraller, bazı antioksidanlar ve anti-kanserojen maddeler bakımından zengin olduğundan sağlık açısından da oldukça yararlıdır (Li ve ark., 2017; Michels ve ark., 2020). Son çalışmalar yulaf tüketiminin kardiyovasküler hastalık riskindeki azalmadan (Grundy ve ark., 2018) bazı kanser türlerinin önlenmesine (Meydani, 2009) kadar insan sağlığı üzerindeki birçok faydalı etkisini ortaya koymuştur. Ayrıca, yulafın içerdiği çözünür diyet lifi olan $\beta$-glukanın insanlarda kandaki kolestrol ve kan glukoz seviyelerini düşürdüğü, kroner kalp hastalıklarına yakalanma riskini azalttığı, bağışıklık sistemini güçlendirmeye yardımcı olduğu belirlenmiştir (Tiwari ve Enda, 2009). Yaygın olarak, iyi bir at yemi olarak bilinmesinin yanında aynı zamanda tüm genç hayvanlar, süt hayvanları ve kümes hayvanları içinde iyi bir yem kaynağıdır (Acar ve ark., 1995). Kullanım amacına göre besin içerikleri farklı yulaflar tercih edilebilmektedir. Hayvan beslenmesinde yulaftan en iyi şekilde yararlanabilmek için yulaf tanesinin yağ ve protein oranının yüksek, bunun aksine $\beta$-glukan oranının ise düşük olması istenmektedir. İnsan beslenmesinde ise yağ oranının ise düşük, protein ve $\beta$-glukan oranının yüksek olması istenmektedir (Peterson ve ark., 2005). Son yıllarda yulafin; un, gevrek, kepek olarak kahvaltılık ürünlerde, birçok endüstriyel gıdaların içerisinde, ilaç ve kozmetik sanayinde kullanımı artmış ve popular bir bitki haline gelmiştir.

Ülkemizde son yıllarda mevcut tarımı yapılan türlere alternatif olabilecek sulamasız şartlarda dekara verimi ve besin değeri yüksek bitkilerin arayışları hızla artmaktadır. Yulaf özellikle Orta Anadolu Bölgesi'nde mevcut üretilen bitkiler ile münavebeye girebilecek önemli bir tahıldır. Diğer bütün ürünlerde olduğu gibi yulaf çeşitlerinde de yüksek tane verimi en çok istenen özelliktir (Tamm, 2003). Fakat günümüzde verim kadar kalitede yulafta ön plana çıkmıştır.

Kalite ve verim açısından üstün çeşit veya genotiplerin belirlenmesi, ürün çeşitliğini ve daha ekonomik üretimi sağlayacaktır. Verim ve kalite üzerine çeşit kadar bölgelere göre değişen çevre koşulları ve yetiştirme teknikleri etkili olmaktadır. Verimde önemli artışlar sağlayan sulama, yetiştirmede uygulanan önemli faktörler arasında yer almaktadır. Kuru tarım alanlarında yetiştirme tekniklerinin kullanılması, uygun çeşit ve iyi tohumluk kullanılması, sulu tarım alanlarında yulaf yetiştiriciliğine yer verilmesi verimi ve kaliteyi artırmak için gerekli uygulamalar olarak ön plana çıkmaktadır. Bu çalışmanın amacı; Yozgat koşullarında hem yağışa dayalı hem de destek sulama ile sulanan koşullarda farklı yulaf çeşit ve genotiplerinin tane kalite özelliklerini belirlemektir.

\section{Materyal ve Yöntem}

Bu çalışmada, Checota, Yeniçeri, Kahraman ve Kırklar olmak üzere tescilli dört çeşit ve 18 ileri seviyedeki hat ile birlikte toplam 22 yulaf genotipi materyal olarak kullanılmıştır. Çizelge 1'de denemede yer alan genotiplerin isim ve pedigrileri verilmiştir.

Denemeler, 2016-2017 yetiştirme döneminde Yozgat Bozok Üniversitesi Ziraat Fakültesi Yerköy deneme alanında yürütülmüştür. Deneme alanının toprak yapısı orta derecede kireçli, hafif alkali, fosfor içeriği orta, potasyumca zengin, hafif tuzlu, organik madde bakımından fakir killi-tınlı bir yapıya sahiptir.

Deneme y1lına ve uzun y1llara ait ilkim verileri Çizelge 2'de verilmiştir. Çizelge 2' de görüldüğü gibi, 20162017 yetiştirme yılında ve uzun yıllarda sırasıyla ortalama sıcaklık $6.8{ }^{\circ} \mathrm{C}$ ve $6.9{ }^{\circ} \mathrm{C}$, toplam yağış 416.9 ve 553.2 $\mathrm{mm}$, ortalama nispi nem \% 63.9 ve 68.9 olmuştur.

Çalışmada yulaf genotipleri yağışa dayalı ve destekleme sulama ile sulanan olmak üzere iki ayrı denemede denenmiştir. Ekim işlemi parsel ekim mibzeri ile m2'de 500 tohum olacak şekilde yapılmıştır. $12 \mathrm{~m}$ uzunluğunda 1.2 m genişliğinde parsellere 6 sıra olarak 20 Eylül 2016 tarihinde yapılmıştır. Üç tekerrürlü olarak Tesadüf Blokları Deneme Desenine göre kurulan denemelerde parsel arasında 1'er metre, blok aralarında 2'şer metre mesafe bırakılmıştır. Gübre uygulaması dekara $8 \mathrm{~kg}$ saf N ve $8 \mathrm{~kg}$ P2O5 olacak şekilde yapılmıştır. Fosforlu gübrenin tümü, azotlu gübrenin ise 1 12 'si ekimle birlikte, 112'si ise kardeşlenme döneminde üst gübresi olarak uygulanmıştır. 
Çizelge 1. Denemede kullanılan genotiplerin isim ve pedigrileri

Table 1. The names and pedigrees of the genotypes used in the trial

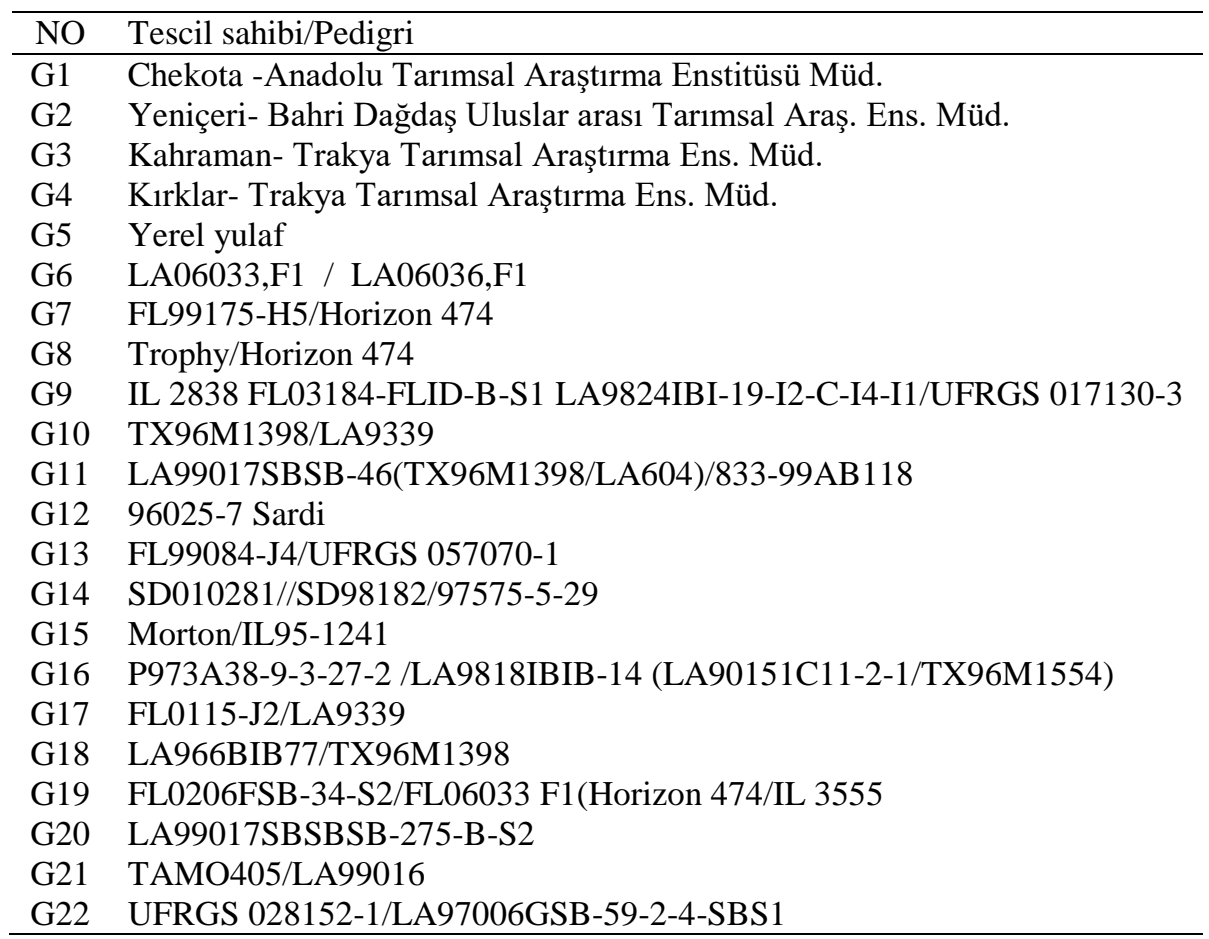

Çizelge 2. Deneme yılı ve uzun yıllar ortalamasına ait iklim verileri

Table 2. Some climate data regarding trial year and long years average

\begin{tabular}{lcccccc}
\hline \multirow{2}{*}{ Aylar } & \multicolumn{2}{c}{ Yă̆ı̧ $(\mathrm{mm})$} & \multicolumn{2}{c}{ Sicaklık $\left({ }^{\circ} \mathrm{C}\right)$} & \multicolumn{2}{c}{ Nispi Nem ( \% ) } \\
\cline { 2 - 6 } & $2016-2017$ & Uzun yıllar & $2016-2017$ & Uzun yıllar & $2016-2017$ & Uzun y1llar \\
\hline Eylül & 15.0 & 18.0 & 15.4 & 15.5 & 56.6 & 58.1 \\
Ekim & 3.0 & 36.5 & 11.0 & 10.3 & 58.3 & 65.9 \\
Kasım & 43.8 & 56.2 & 5.0 & 4.6 & 54.8 & 72.5 \\
Aralık & 75.7 & 76.3 & -3.3 & 0.5 & 78.9 & 77.3 \\
Ocak & 52.8 & 67.9 & -3.5 & -1.9 & 77.5 & 77.5 \\
Şubat & 11.6 & 62.3 & -0.4 & -1.0 & 69.4 & 75.8 \\
Mart & 87.6 & 65.2 & 5.1 & 2.9 & 63.5 & 71.0 \\
Nisan & 46.8 & 62.3 & 8.3 & 8.3 & 55.2 & 66.6 \\
Mayis & 24.1 & 65.0 & 12.4 & 13.0 & 63.6 & 64.2 \\
Haziran & 56.5 & 43.5 & 17.6 & 16.8 & 61.2 & 60.5 \\
Ort./Top. & 416.9 & 553.2 & 6.8 & 6.9 & 63.9 & 68.9 \\
\hline
\end{tabular}

Daha önce yapılmış olan sulama çalışmaları, yetiştirilen bitkinin ve toprağın durumu dikkate alınarak destekleme su uygulaması yapılan tüm parsellere, sapa kalkma döneminde bir kez su verilmesine karar verilmiştir. Denemede yabancı otları kontrol etmek için herbisit kullanılmıştır. Hasat işlemi kenar tesir atıldıktan sonra motorlu tırpan ile toprak yüzeyinden $5 \mathrm{~cm}$ yükseklikten biçilerek yapılmıştır. Biçildikten sonra parsellerde kurumaya bırakılan örnekler parsel harman makinesi ile harmanlanmıştır. Harmandan sonra elde edilen taneler laboratuvar analizlerin kadar $+4{ }^{\circ} \mathrm{C}$ 'de buzdolabında muhafaza edilmiştir. Çalışmada asit deterjanda çözünmeyen lif (ADF) ve nötr deterjanda çözünmeyen lif (NDF) değerleri, nişasta, protein, $\beta$-glukan ve yağ oranları ile yağ asidi içerikleri (linoleik, oleik, palmitik ve stearik asit) belirlenmiştir. Kimyasal analizlerden ADF ve NDF değerleri Van Soest ve ark. (1991)'na; nişasta; Ewers Polarimetrik'e, yağ analizi; Soxhlet; protein analizi; Kjeldahl ve $\beta$-glukan analizi; enzimatik metodlara göre yapılmıştır (AACC, 2005). O'Fallon ve ark. (2007) belirttiği yönteme göre yağ asit kompozisyonu belirlenmiştir. 
Araştırmada sulanan ve sulanmayan denemelerden elde edilen verilerin ayrı ayrı varyans analizleri MSTAT C paket programı kullanılarak Tesadüf Blokları Deneme Desenine göre yapılmıştır. Ortalamalar arasındaki farklılıkların karşılaştırılmasında LSD çoklu karşıllaştırma testi kullanılmıştır.

\section{Bulgular}

\subsection{Yağışa dayalı koşullar}

Varyans analizi sonuçlarına göre yağışa dayalı koşullarda nişasta oranı hariç incelenen bütün özellikler açısından genotipler arasındaki önemli farklılıklar bulunmuştur. İncelenen özelliklere ait ortalama değerler Çizelge 3'de verilmiş̧ir.

Çalışmada, yağışa dayalı koşullarda genotiplerin nişasta oranı \% 37.1 (G19) ile 47.6 (Kahraman), protein oranı \% 12.7 (G19) ile 15.2 (G6) ve $\beta$-glukan oranı \% 3.53 (G5) ile 4.58 (G15), ADF değeri \% 11.9 (G8) ile 16.9 (G19), NDF değeri \% 30.1 (G10) ile 37.1 (H19) arasında değişmiştir. Nişasta oranı bakımından genotipler arasında istatistiki olarak fark bulunmamıştır. Genotipler değerlendirildiğinde protein oranı bakımından $\mathrm{G} 6$ ve Checota, $\beta$ glukan oranı bakımından G8, G9 ve G15 en yüksek değerlere sahip olmuş ve istatistiki olarak aynı grupta yer almıştır. ADF değeri bakımından G8, G6, G15 ve G2 (Yeniçeri) numaralı ve NDF değeri bakımından G10, G6, G15 ve G3 (Kahraman) numaralı genotipler en düşük değerlere sahip olmuştur. Aynı koşullarda, yulaf genotiplerinin yağ içeriği \% 4.64 (Kahraman) ile 7.89 (G10), linoleik asit içeriği \% 28.8 (G10) ile 37.2 (Kahraman), oleik asit içeriği \% 37.1 (Kahraman) ile 47.10 (G10), palmitik asit içeriği \% 21.7 (G20) ile 23.5 (G5) ve stearik asit içeriği \% 1.74 (G12) ile 2.05 (G5) arasında değişmiştir. G10 \% 7.89 yağ içeriği ile diğer genotiplerden oldukça fazla yağ içeriğine sahip olmuştur. Linoleik asit içeriği bakımından Kahraman ve G9, oleik asit içeriği bakımından G7 ve G10, palmitik asit içeriği bakımından G5, G9 ve G19, stearik asit içeriği bakımından Yeniçeri, Kahraman, Kırklar, G5, G6, G10, G14, G16, G18, G20 ve G22 numaralı genotipler en yüksek değerlere sahip olmuş ve istatistiki olarak aynı grupta yer almıştır (Çizelge 3).

Yağışa dayalı koşullarda incelenen özellikler arasındaki korelasyonlar Çizelge 5'de verilmiştir. Çizelge 5 incelendiğinde nişasta oranı ile stearik asit içeriği arasında olumlu ve önemli, ADF ve NDF değerleri arasında ise olumsuz ve önemli ilişki belirlenmiştir. Protein oranı ile ADF ve NDF değerleri arasında olumsuz ve $p>0.01$ seviyesinde önemli ilişki belirlenmiştir. $\beta$-glukan ile stearik asit içeriği arasında olumsuz ve önemli ilişki belirlenmiştir. ADF ve NDF arasında olumlu ve önemli ilişki belirlenirken, NDF ile yağ oranı ve sterarik asit içeriği arasında olumsuz ilişki belirlenmiştir. Yağ oranı ile oleik asit içeriği arasında olumlu ve önemli, linoleik asit içeriği arasında ise olumsuz ve önemli ilişki belirlenmiştir. Oleik asit ile linoleik asit içeriği arasında olumsuz ve önemli ilişki belirlenmiştir.

\subsection{Destek sulamalı koşullar}

Varyans analizi sonuçlarına göre destek sulamalı koşullarda stearik asit içeriği hariç incelenen bütün özellikler bakımından genotipler arasındaki önemli farklar tespit edilmiştir. İncelenen özelliklere ait ortalama değerler Çizelge 4'de verilmiştir.

Çalışmada destek sulamalı koşullarda genotiplerin nişasta oranı \% 39.4 (G19) ile 49.0 (G15), protein oranı \% 12.3 (G20) ile 14.6 (G1) ve $\beta$-glukan oran1 \% 3.44 (G10) ile 4.06 (G9), ADF değeri \% 12.0 (G15) ile 16.3 (H19) ve NDF değeri \% 30.3 (G13) ile 37.5 (H19) arasında değişmiştir. Kahraman ve Kırklar çeşitleri ile G5, G6, G8, G9, G11, G12, G13, G15, G6, G17, G18 ve G20 numaralı genotipler nişasta oranı bakımından istatistiki olarak aynı grupta yer almıştır. Protein oranı bakımından Checota, Yeniçeri ve Kahraman çeşitleri ile G11 numaralı genotip, $\beta$ glukan içeriği bakımından Checota, Kahraman ve Kırklar çeşitleri ile G6, G8, G9, G11, G13, G15, G20 ve G21 numaralı genotipler, ADF değeri bakımından Yeniçeri çeşidi ile G14, G19, G21 ve G22 numaralı genotipler, NDF değeri bakımından G5 ve G19 numaralı genotipler istatistiki olarak aynı grupta yer almış ve en yüksek değerlere sahip olmuşlardır. Sulamalı koşullarda yulaf genotiplerinin yağ içeriği \% 4.87 (G3) ile 8.27 (G10), linoleik asit içeriği \% 29.0 (G10) ile 37.1 (G3), oleik asit içeriği \% 36.3 (G3) ile 46.5 (G10), palmitik asit içeriği \% 22.7 (G17) ile 24.8 (G5) ve stearik asit içeriği \% 1.86 (G19) ile 2.05 (G18) arasında değişmiştir. \% 8.27 yağ oranı ile G10 numaralı genotip en yüksek yağ içeriğine sahip olmuştur. Kahraman çeşidi ile G18 numaralı genotip linoleik asit içeriği bakımından en yüksek değerlere sahip olmuş ve istatistiki olarak aynı grupta yer almıştır. Palmitik asit içeriği bakımından ise G5 numaralı genotip en yüksek değere sahip olmuştur (Çizelge 4).

Destek sulamalı koşullarda incelenen kalite özellikleri arasındaki korelasyonlar Çizelge 6'de verilmiştir. nişasta oranı ile linoleik asit ve stearik asit arasında olumlu ve önemli, ADF ve NDF değeri arasında olumsuz ve önemli ilişki belirlenmiştir. Protein oranı ile ADF ve NDF değeri arasında olumsuz ve önemli ilişki belirlenmiştir. $\beta$-glukan içeriği ile linoleik asit içeriği arasında olumlu ve önemli ilişki, NDF değeri ve yağ oranı arasında ise olumsuz ve önemli ilişki belirlenmiştir. ADF değeri ile NDF arasında olumlu ve önemli, stearik asit içeriği ile olumsuz ve 
önemli ilişki belirlenmiştir. NDF ile stearik asit içeriği arasında olumsuz ve önemli ilişki belirlenmiştir. Yağ oranı ile oleik asit içeriği arasında olumlu ve önemli ilişki, linoleik asit içeriği ile olumsuz ve önemli ilişki belirlenmiştir. Linoleik asit ile oleik asit arasında olumsuz ve önemli ilişki belirlenmiştir.

\section{Tartışma}

Yağışa dayalı koşullarda ve destek sulamalı koşullarda ortalama nişasta oranı sırasılyla \% 43.6 ve \% 44.4, protein oranı sırasıyla \% 13.9 ve \% 13.4 ve $\beta$-glukan oranı \% 3.90 ve \% 3.78 olarak belirlenmiştir (Çizelge 3 ve 4 ). Hem insan gıdasında hem de hayvan beslemede nişasta, protein ve $\beta$-glukan oranı çok önemlidir. Yetiştirilen bölgedeki sıcaklık, toprak özellikleri, yağış miktarı, yağışın aylara göre dağılımı ve kültürel uygulamalar tahılların tane kalitesini etkilemektedir (Mut ve ark., 2017). Çalışmada, yağışa dayalı denemeye kıyasla su uygulanan denemede genotiplerin nişasta içeriğinin yüksek, protein ve $\beta$-glukan içeriğinin ise daha düşük tespit edilmiştir (Çizelge 3). Doehlert ve ark. (2001) ile Mut ve ark. (2018)'nın yaptıkları çalışmada yulaf tanesinde nişasta, protein ve $\beta$-glukan oranın genotiplerden, çevresel faktörlerden ve yıllardan etkilendiğini bildirmişlerdir. İnsan ve hayvan beslenmesinde önemli bir enerji kaynağı olan nişasta, yulaf tanesi içinde $\beta$-glukan ve protein açısından zengin kepek katmanları ile çevrili endospermde bulunur (Punia ve ark., 2020). Nişasta bitkilerde bulunan temel sindirilebilir karbonhidrattır. Ayrıca yulaf tanesinin protein oranının yüksek olması istenmektedir. Yulaf tanesinde de bulunan $\beta$-glukanlar, kandaki kolestrol ve kan glukoz seviyelerini düşürdüğü ve insanlarda bağışıklık sistemini güçlendirdiği belirlenen doğal liflerdir (Tiwari ve Cummins, 2009). $\beta$-glukan içeriğinin insan gıdası olarak kullanılacak yulaflarda yüksek, hayvan beslemede kullanılacak yulaflarda düşük olması istenmektedir (Peterson ve ark., 2005). Yapılan çalışmalarda, nişasta oranının \% 34.9 ile 49.6 (Brunava ve ark., 2014; Mut ve ark., 2016; Mut ve ark. 2018), protein oranının \% 8.8 ile 14.8 (Mut ve ark., 2016; Mut ve ark. 2018) ve $\beta$-glukan oranının \% 4.1 ile 5.07 (Brunova ve ark., 2014; Mut ve ark., 2018) arasında değiştiği bildirilmiştir.

Çalışmada yağışa dayalı ve destek sulamalı koşullarda ortalama ADF değeri sırasıyla \%13.5 ve \%13.9 olurken, NDF değeri sırasıyla \% 32.6 ve \% 33.4 olarak belirlenmiştir (Çizelge 3 ve Çizelge 4). ADF bitki hücre duvarı yapısındaki lignin, selüloz ve çözünmeyen protein miktarını, NDF ise bitki hücre duvarı yapısında bulunan lignin, selüloz, hemi-selüloz, çözünmeyen protein miktarını ve kütin ifade etmektedir. Yemlerden kuru maddede ADF değeri \% 10-15 arasında, NDF değeri \% 30'u aşmayacak düzeyde olduğunda optimum verim elde edileceği bildirilmiştir (National Research Council, 2001). ADF değeri düşük olması yemlerin sindirilebilirliği ve enerji değerini arttırırken (Van Dyke ve Anderson, 2000), NDF değerinin düşük olması ise hayvanın yem alımını arttırmaktadır (Van Soest ve ark., 1991). Mut ve ark (2018)'nın yaptıkları çalışmada, ADF ve NDF içeriğinin genotip ve çevreden etkilendiğini, ADF içeriğinin \% 14.2 ile 16.4, NDF içeriğinin ise \% 31.5 ile 34.4 arasında değiştiğini bildirmişlerdir.

Yağışa dayalı ve destek sulamalı koşullarda genotiplerin ortalama yağ oranı, linoleik, oleik, palmitik, stearik asit içerikleri sırasıyla $\% 6.09$ ve $\% 6.35, \% 33.8$ ve $\% 33.9, \% 41.3$ ve $\% 40.5, \% 22.4$ ve $\% 23.3, \% 1.89$ ve $\% 1.96$ olarak belirlenmiş̧ir. Yağlar hücre zarlarının yapısal bir bileşeni, enerji deposu ve sinyal yollarındaki performans gibi farklı görevlere sahip çeşitli bileşikler grubudur (de Oliveira Maximino ve ark., 2020). Yulaf taneleri genellikle diğer tahıl tanelerinden daha fazla yağ ve daha sağlıklı yağ asidi kompozisyonuna sahiptir (Carlson ve ark., 2019). Yulaf yağının değerli yağ asidi bileşimi nedeniyle beslenme potansiyeli yüksektir. Yulaf tanelerinin yağ içeriğinin genetik ve çevresel faktörlere göre değiştiği bildirilmiştir (Martinez ve ark., 2010; Hawerroth ve ark., 2013; Mut ve ark., 2017; Mut ve ark., 2018; Bağcı ve ark., 2019). Martinez ve ark. (2010) yaptıkları çalışmada yulaf genotiplerinin yağ içeriğinin \% 3.1 ile 11.6 arasında değiştiğini bildirmişlerdir. Hayvan beslemede yüksek yağ içeriğine sahip yulaf tanesi yüksek kalori sağlayacağından arzu edilen bir durumudur (Martinez ve ark., 2010; Silveria ve ark., 2016). Fakat gıda uygulamalarında yüksek yağ içeriği bayatlama ve lezzetsiz ürün üretimine neden olacağından istenmeyen bir durumdur (Doehlert ve ark., 2001). Kullanım amacına göre yulaf tanesinde istenen yağ içeriği değiştiğinden, yulafin yağ kompozisyonunun korunması ve/veya en uygun düzeyde tutulması önemli bir sslah amacı haline gelmiştir (Valentine ve ark., 2011). Yapılan çalışmalarda yağ içeriğini \% 2.7 ile 8.1 arasında değiştiği bildirilmiştir. (Mut ve ark., 2016; Mut ve ark., 2018; Bityutskii ve ark., 2020). Bağcı ve ark. (2019) yaptıkları çalışmada, yulaf tanesinde oleik, linoleik, palmitik, linoleik ve stearik asit içeriklerinin sırasıyla \% 19.59 ile 37.86, \% 18.91 ile 54.00, \% 10.82 ile 22.43, \% 2.43 ile 8.34 ve \% 1.25 ile 7.74 arasında değiştiğini bildirmişlerdir. Yapılan birçok çalışmada, çalışmamıza benzer olarak yulaf tanesinde en fazla bulunan oleik, linoleik ve palmitik yağ asitleri olmuş ve yağ asidi bileşimleri ile ilgili sonuçlarımız literatürle karşılaştırıldığında küçük farklılıklar göstermektedir (Mut ve ark., 2016; Carlson ve ark., 2019; Bityutskii ve ark., 2020). Bağcı ve ark. (2020) bu farklılıkların genetik faktörler, çevresel faktörler, yetiştirme koşulları ve analitik prosedürlerden kaynaklanabileceğini bildirmiştir.

Farklı çevrelerde yapılan çalı̧̧malarda yulafın kalite özellikleri bakımından önemli yada önemsiz olumlu ve olumsuz korelasyonların ortaya çıtığı bildirilmiştir (Peterson ve ark., 2005; Martinez ve ark., 2010; Mut ve ark., 2016). Yulafta yapılan önceki çalışmalarda Martinez ve ark. (2010) protein oranı ile nötr deterjanda çözünmeyen lif içeriği ve oleik asit ile linoleik asit içeriği arasında negatif bir ilişki olduğunu bildirmişlerdir. Mut ve ark. (2017) 
Çizelge 3. Yağışa dayalı koşullarda yetiştirilen yulaf genotiplerinin bazı kalite özelliklerine ait ortalama değerler

Table 3. Average values of some quality traits of oat genotypes grown under rainfall conditions

\begin{tabular}{|c|c|c|c|c|c|c|c|c|c|c|}
\hline & Nişasta oranı & Protein oranı & p-glukan oranı & ADF değeri & NDF değeri & Yağ oranı & Linoleik asit & Oleik asit & Palmitik asit & Stearik asit \\
\hline G1 (Checota) & 42.9 & 15.1 & 3.97 & 12.9 bcd & 32.5 cde & 6.22 def & 34.0 & 40.5 efg & 22.8 b-e & 1.85 b-g \\
\hline G2 (Yeniçeri) & 45.2 & 13.6 e-h & 3.57 & 12.5 & 32.9 b-e & 6.41 cde & 32.8 & 42.7 cd & 22.1 & $1.99 \mathrm{ab}$ \\
\hline G3 (Kahraman) & 47.6 & 13.9 & 3.98 & 13.2 bcd & 31.2 & 4.64 & 37.2 & 37.1 & 22.1 & 1.89 a-g \\
\hline G4 (Kırklar) & 43.3 & 13.9 & 3.98 & 12.7 & 31.8 cde & 6.00 efg & 34.3 & 40.6 efg & 22.4 & 1.91 a-f \\
\hline G5 & 42.8 & 14.1 & 3.53 & 14.0 bcd & 32.8 b-e & 6.11 efg & 34.3 & $39.8 \mathrm{fg}$ & 23.5 & 2.05 \\
\hline G6 & 45.0 & 15.2 & 3.92 & 12.1 & 30.8 de & 6.20 def & 33.9 & 41.3 def & 22.3 & 1.95 a-d \\
\hline G7 & 39.9 & 13.5 & 3.58 & 15.0 abc & 32.3 cde & 7.30 & 31.2 & $44.9 \mathrm{ab}$ & 22.3 & 1.86 b-g \\
\hline G8 & 45.2 & 14.6 & 4.29 & 11.9 & 32.2 cde & 5.91 fgh & 34.0 & 41.2 def & 22.3 & 1.85 b-g \\
\hline G9 & 43.9 & 14.2 & 4.31 & 13.4 bcd & 32.2 cde & $5.13 \mathrm{j}$ & 36.5 & 37.6 hi & 22.8 abc & 1.79 efg \\
\hline G10 & 44.6 & 14.0 & 3.63 & 12.9 bcd & 30.1 & 7.89 & 28.8 & 47.9 & 22.8 bcd & $1.98 \mathrm{abc}$ \\
\hline G11 & 44.4 & 13.3 & 3.92 & 14.0 bcd & 33.5 bcd & 5.52 hij & 35.4 & 39.1 gh & $22.6 \quad$ b-g & 1.88 b-g \\
\hline G12 & 40.1 & 13.7 & 3.91 & 15.3 & 36.0 & 5.92 fgh & 34.5 & 40.2 efg & $22.6 \quad b-g$ & 1.74 \\
\hline G13 & 40.9 & 14.1 & 4.10 & 13.6 bcd & 32.2 cde & $6.57 \mathrm{~cd}$ & 32.7 & 43.2 bc & 22.1 & 1.83 c-g \\
\hline G14 & 44.8 & 14.3 & 3.64 & 13.5 bcd & 32.6 cde & 6.27 def & 33.2 & 41.2 def & 22.7 & 1.95 a-d \\
\hline G15 & 44.6 & 14.3 & 4.38 & 12.3 & 31.2 & 5.95 fgh & 34.2 & 41.1 def & 22.2 & 1.78 fg \\
\hline G16 & 43.9 & 13.9 & 3.97 & 12.8 & 32.3 cde & 6.08 efg & 34.1 & 40.8 efg & 22.5 b-h & 1.90 a-f \\
\hline G17 & 44.9 & 13.9 & 4.13 & 12.9 bcd & 32.1 cde & $6.59 \mathrm{~cd}$ & 32.9 & $43.1 \quad \mathrm{c}$ & 22.0 & 1.87 b-g \\
\hline G18 & 46.1 & 13.0 & 3.74 & 12.9 bcd & 32.7 b-e & 5.34 & 35.5 & $39.7 \mathrm{fg}$ & 21.9 & 1.93 a-e \\
\hline G19 & 37.1 & 12.7 & 3.64 & 16.9 & 37.1 & 5.16 & 34.1 & 40.1 efg & 23.0 & $1.82 \mathrm{~d}-\mathrm{g}$ \\
\hline G20 & 44.1 & 13.5 & 3.77 & 14.3 bcd & 33.1 b-e & 5.67 ghi & 34.2 & 41.5 cde & 21.7 & 1.89 a-g \\
\hline G21 & 43.8 & 14.1 cde & 4.01 & 13.9 bcd & 31.9 cde & 6.80 & 33.1 & 42.7 cd & 21.8 & 1.88 b-g \\
\hline G22 & 44.8 & 13.1 & 3.89 & 13.7 bcd & 34.7 abc & 6.21 def & 33.7 & 41.6 cde & 22.2 & 1.92 a-f \\
\hline Ortalama & 43.6 & 13.9 & 3.90 & 13.5 & 32.6 & 6.09 & 33.8 & 41.3 & 22.4 & 1.89 \\
\hline LSD (0.05) & $6.89^{\text {öd }}$ & $0.54^{* *}$ & $0.24^{* *}$ & $2.45^{*}$ & $3.35 *$ & $0.45 *$ & $1.56^{* *}$ & $1.75^{* *}$ & $0.62 * *$ & $0.16^{*}$ \\
\hline VK (\%) & 9.6 & 2.3 & 3.8 & 11.1 & 6.2 & 4.5 & 2.8 & 2.6 & 1.7 & 4.9 \\
\hline
\end{tabular}

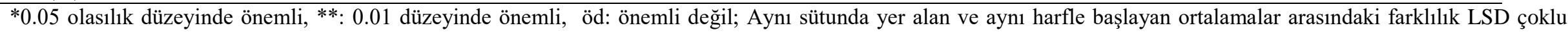
karşılaştırma testine göre istatistiksel olarak önemsizdir $(\mathrm{P}<0.05)$. 
Çizelge 4. Destek sulamalı koşullarda yetiştirilen yulaf genotiplerinin bazı kalite özelliklerine ait ortalama değerler

Table 4. Average values of some quality traits of oat genotypes grown under supplemented irrigation

\begin{tabular}{|c|c|c|c|c|c|c|c|c|c|c|c|c|c|c|c|c|c|c|c|}
\hline \multirow[b]{2}{*}{ G1 (Checota) } & \multicolumn{2}{|c|}{ Nişasta oranı } & \multicolumn{2}{|c|}{ Protein oranı } & \multicolumn{2}{|c|}{$\beta$-glukan oranı } & \multicolumn{2}{|c|}{ ADF değeri } & \multicolumn{2}{|c|}{ NDF değeri } & \multicolumn{2}{|c|}{ Yağ oranı } & \multicolumn{2}{|c|}{ Linoleik asit } & \multicolumn{2}{|c|}{ Oleik asit } & \multicolumn{2}{|c|}{ Palmitik asit } & \multirow{2}{*}{$\begin{array}{c}\text { Stearik asit } \\
2.04\end{array}$} \\
\hline & 43.0 & b-g & 14.6 & $\mathrm{a}$ & 3.87 & $\mathrm{a}-\mathrm{d}$ & 13.4 & cde & 31.7 & ef & 6.67 & c & 32.2 & $\mathrm{i}$ & 42.0 & c & 23.6 & bcd & \\
\hline G2 (Yeniçeri) & 40.0 & fg & 14.0 & abc & 3.71 & $c-g$ & 14.9 & abc & 33.4 & cde & 6.69 & c & 33.0 & hi & 40.8 & $c-f$ & 23.7 & $\mathrm{~b}$ & 1.97 \\
\hline G3 (Kahraman) & 45.2 & a-e & 14.3 & $\mathrm{ab}$ & 3.91 & $a-d$ & 13.6 & b-e & 32.8 & cde & 4.87 & $\mathrm{~h}$ & 37.1 & $\mathrm{a}$ & 36.3 & $\mathrm{i}$ & 23.4 & $b-f$ & 1.97 \\
\hline G4 (Kırklar) & 45.4 & $\mathrm{a}-\mathrm{d}$ & 13.8 & bcd & 4.00 & $a b$ & 13.9 & bcd & 32.1 & ef & 6.27 & $c-f$ & 33.7 & e-h & 41.1 & $c-f$ & 23.3 & b-g & 2.00 \\
\hline G5 & 44.6 & $a-f$ & 13.9 & bc & 3.65 & d-g & 13.8 & b-e & 35.8 & $\mathrm{ab}$ & 6.52 & $\mathrm{~cd}$ & 34.0 & d-h & 38.9 & gh & 24.8 & $\mathrm{a}$ & 1.93 \\
\hline G6 & 46.3 & $\mathrm{ab}$ & 13.0 & $f-i$ & 3.78 & a-e & 13.5 & b-e & 33.5 & cde & 6.12 & d-g & 34.7 & b-e & 39.1 & gh & 23.6 & bc & 2.03 \\
\hline G7 & 40.9 & d-g & 13.2 & e-h & 3.49 & fg & 14.0 & bcd & 34.8 & bc & 7.70 & $\mathrm{~b}$ & 30.8 & $\mathrm{j}$ & 44.6 & b & 23.1 & b-g & 1.96 \\
\hline G8 & 46.7 & $\mathrm{ab}$ & 13.6 & $c-f$ & 3.94 & $\mathrm{abc}$ & 12.7 & de & 33.1 & cde & 6.37 & cde & 33.8 & d-h & 40.8 & $c-f$ & 23.0 & d-g & 1.91 \\
\hline G9 & 45.9 & $\mathrm{ab}$ & 13.5 & C-g & 4.06 & $\mathrm{a}$ & 13.5 & b-e & 32.3 & ef & 5.78 & fg & 34.8 & b-e & 39.4 & fgh & 23.2 & b-g & 1.90 \\
\hline G10 & 43.2 & b-g & 13.5 & C-g & 3.44 & g & 14.1 & bcd & 33.7 & cde & 8.27 & $\mathrm{a}$ & 29.0 & $\mathrm{k}$ & 46.5 & $\mathrm{a}$ & 23.4 & $b-f$ & 1.89 \\
\hline G11 & 45.6 & $\mathrm{abc}$ & 14.0 & $\mathrm{abc}$ & 3.92 & $a-d$ & 13.7 & b-e & 32.0 & ef & 6.26 & $c-f$ & 34.3 & C-g & 40.4 & C-g & 22.9 & efg & 1.93 \\
\hline G12 & 45.9 & $\mathrm{ab}$ & 13.8 & bcd & 3.76 & b-f & 14.1 & bcd & 32.5 & de & 6.19 & $c-f$ & 34.7 & b-e & 39.7 & e-h & 23.1 & b-g & 1.95 \\
\hline G13 & 46.3 & $\mathrm{ab}$ & 13.8 & bcd & 3.85 & $a-d$ & 13.1 & cde & 30.3 & $\mathrm{f}$ & 6.65 & C & 33.4 & fgh & 41.0 & $c-f$ & 23.3 & b-g & 2.04 \\
\hline G14 & 41.0 & C-g & 12.4 & $\mathrm{jk}$ & 3.68 & C-g & 15.4 & $a b$ & 34.8 & bc & 6.44 & cde & 32.9 & hi & 41.0 & $c-f$ & 23.4 & b-e & 1.95 \\
\hline G15 & 49.0 & $\mathrm{a}$ & 13.5 & C-g & 3.94 & abc & 12.0 & $\mathrm{e}$ & 32.4 & de & 6.19 & $c-f$ & 34.2 & C-g & 40.3 & C-g & 22.9 & efg & 2.02 \\
\hline G16 & 45.9 & $\mathrm{ab}$ & 13.3 & d-h & 3.77 & $b-f$ & 13.5 & cde & 33.5 & cde & 5.94 & efg & 34.4 & $b-f$ & 39.6 & e-h & 23.2 & b-g & 1.97 \\
\hline G17 & 44.9 & a-e & 13.0 & ghi & 3.73 & $b-f$ & 14.0 & bcd & 34.6 & bc & 6.37 & cde & 34.3 & C-g & 40.1 & d-h & 22.7 & $\mathrm{~g}$ & 1.89 \\
\hline G18 & 48.1 & $\mathrm{a}$ & 13.2 & $\mathrm{f}-\mathrm{i}$ & 3.52 & efg & 13.0 & de & 32.4 & de & 5.65 & g & 35.5 & $a b$ & 38.5 & $\mathrm{~h}$ & 23.0 & d-g & 2.05 \\
\hline G19 & 39.4 & g & 12.6 & ijk & 3.50 & efg & 16.3 & $\mathrm{a}$ & 37.5 & $\mathrm{a}$ & 5.74 & fg & 34.9 & bcd & 38.7 & gh & 23.4 & b-e & 1.86 \\
\hline G20 & 45.9 & $a b$ & 12.3 & $\mathrm{k}$ & 3.95 & abc & 13.0 & de & 33.1 & cde & 5.95 & efg & 35.4 & bc & 39.3 & fgh & 22.8 & fg & 1.93 \\
\hline G21 & 40.5 & efg & 12.9 & hij & 3.90 & $\mathrm{a}-\mathrm{d}$ & 16.0 & $\mathrm{a}$ & 34.5 & bcd & 6.61 & $\mathrm{~cd}$ & 33.0 & hi & 41.7 & $\mathrm{~cd}$ & 23.1 & C-g & 1.87 \\
\hline G22 & 43.0 & b-g & 13.0 & $f-i$ & 3.73 & b-f & 14.4 & $a-d$ & 33.4 & cde & 6.46 & cde & 33.3 & ghi & 41.2 & cde & 23.4 & $b-f$ & 1.98 \\
\hline Ortalama & 44. & & 13. & & 3.7 & & 13 & & 33 & & 6.3 & & 33 & & 40 & & 23. & & 1.96 \\
\hline LSD (0.05) & 4.73 & & 0.56 & & 0.29 & & 1.86 & & 2.0 & & 0.5 & & 1.15 & & 1.73 & & 0.60 & & $0.15^{\text {öd }}$ \\
\hline VK (\%) & 6.5 & & 2. & & 4.6 & & 8. & & 3. & & 5. & & 2. & & 2. & & $1 .($ & & 4.5 \\
\hline
\end{tabular}

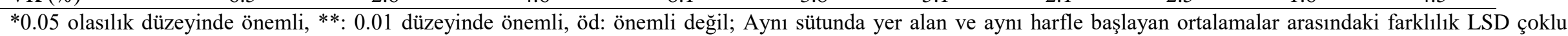
karşılaştırma testine göre istatistiksel olarak önemsizdir $(\mathrm{P}<0.05)$. 
protein oranı ve nişasta oranı ile asit ve nötr deterjanda çözünmeyen lif değerleri arasında negatif bir ilişki olduğunu bildirmişlerdir. Mut ve ark. (2016) yağ oranı ile $\beta$-glukan içeriği arasında negatif korelasyonların olduğu bildirmişlerdir. Bityutskii ve ark. (2020) yağ içeriği ile oleik asit içeriği arasında pozitif, linoleik asit içerikleri arasında ise negatif ilişki belirlemişlerdir.

Çizelge 5. Sulamasız koşullarda incelenen özellikler arasındaki korelasyon katsayıları ve önemlilikleri

Table 5. Correlation coefficients and significance between investigated traits in non-irrigated conditions

\begin{tabular}{lccccccccc}
\hline & NO & PO & BGO & ADF & NDF & YO & LA & OA & PA \\
\cline { 2 - 9 } PO & 0.289 & & & & & & & & \\
AGO & 0.232 & 0.401 & & & & & & & \\
ADF & $-0.785^{* *}$ & $-0.569^{* *}$ & -0.341 & & & & & & \\
NDF & $-0.566^{* *}$ & $-0.438^{*}$ & 0.122 & $0.752^{* *}$ & & & & & \\
YO & -0.129 & 0.194 & -0.263 & -0.158 & $-0.601^{* *}$ & & & \\
LA & 0.235 & -0.033 & 0.380 & 0.045 & $0.471^{*}$ & $-0.942^{* *}$ & & & \\
OA & -0.147 & 0.013 & -0.288 & -0.124 & $-0.509^{*}$ & $0.934^{* *}$ & $-0.978^{* *}$ & & \\
PA & -0.389 & 0.117 & -0.264 & 0.373 & 0.190 & -0.007 & -0.041 & -0.148 & \\
SA & $0.411^{*}$ & 0.024 & $-0.652^{*}$ & -0.341 & $-0.692^{* *}$ & 0.272 & -0.267 & 0.22 & 0.138 \\
\hline
\end{tabular}

*0.05 olasılık düzeyinde önemli, **: 0.01 düzeyinde önemli, YD: Yağışa dayalı koşullar, DS: Destek sulamalı koşullar, NO: Nişasta oranı, PO: Protein oranı, $\beta \mathrm{GO}$ : $\beta$-glukan oranı, ADF: Asit deterjanda çözünmeyen lif, NDF: Nötr deterjanda çözünmeyen lif, YO: yağ oranı, LA: Linoleik asit içeriği, OA: Oleik asit içeriği, PA: Palmitik asit içeriği, SA: Stearik asit içeriği

Çizelge 6. Destek sulamalı koşullarda incelenen özellikler arasındaki korelasyon katsayıları ve önemlilikleri

Table 6. Correlation coefficients and significance between investigated traits in supplemented irrigation

\begin{tabular}{lccccccccc}
\hline & NO & PO & BGO & ADF & NDF & YO & LA & OA & PA \\
\cline { 2 - 9 } PO & 0.129 & & & & & & & & \\
BGO & 0.398 & 0.253 & & & & & & & \\
ADF & $-0.874^{* *}$ & $-0.430^{*}$ & -0.329 & & & & & \\
NDF & $-0.547^{* *}$ & $-0.480^{*}$ & $-0.495^{*}$ & $0.577^{* *}$ & & & & \\
YO & -0.372 & 0.049 & $-0.458^{*}$ & 0.127 & 0.086 & & & \\
LA & $0.457^{*}$ & -0.097 & $0.429^{*}$ & -0.203 & -0.086 & $-0.969^{* *}$ & & & \\
OA & -0.36 & 0.042 & -0.343 & 0.118 & -0.010 & $0.957^{* *}$ & $-0.972^{* *}$ & & \\
PA & -0.294 & 0.369 & -0.242 & 0.229 & 0.286 & 0.100 & -0.122 & -0.086 & \\
SA & $0.430^{*}$ & 0.408 & 0.073 & $-0.537^{* *}$ & $-0.598^{* *}$ & -0.127 & 0.108 & -0.119 & 0.09 \\
\hline
\end{tabular}

*0.05 olasılık düzeyinde önemli, **: 0.01 düzeyinde önemli, YD: Yağışa dayalı koşullar, DS: Destek sulamalı koşullar, NO: Nişasta oranı, PO: Protein oranı, $\beta G O$ : $\beta$-glukan oranı, ADF: Asit deterjanda çözünmeyen lif, NDF: Nötr deterjanda çözünmeyen lif, YO: yağ oranı, LA: Linoleik asit içeriği, OA: Oleik asit içeriği, PA: Palmitik asit içeriği, SA: Stearik asit içeriği

\section{Sonuç}

Yulaf tanesinin kalitesi birçok faktörün etkisi ile şekillenmektedir. Yozgat koşullarında yürütülen araştırmada, yapılan destek sulamanın incelenen özellikler açısından genotiplerin farklı tepki verdiği belirlenmiştir. Yağışa dayalı koşullarda G3, G6, G8, G9 ve G15 numaralı genotipler, destek sulamalı koşullarda G3, G8, G9, G11, G13 ve G15 numaralı genotipler nişasta, protein ve $\beta$-glukan içeriği bakımından ortalamanın üstünde, ADF ve NDF değerlerleri bakımından ise düşük değerlere sahip olmuşlardır. Hem yağışa bağlı hem de sulanan şartlarda G9 numaralı genotip birçok kalite özelliği bakımından ortalama değerlerin üzerinde olmuştur. İstenilen kalite özellikleri bakımından üstün özellik gösteren genotipler yapılacak daha geniş lokasyon çalışması sonucunda tescil edilebileceği gibi yulaf ıslahında genitör olarakta kullanılabilir.

\section{Teşekkür}

Bu makaledeki verilerin bir kısmı Necibe Demirtaş'ın Yüksek Lisans tezinde kullanılmıştır. 
AACC. 2005. American Association of Cereal Chemists. Approved Methods of the AACC (11th ed.). St. Paul, USA. https://methods.aaccnet.org/about.aspx.

Acar, Z., Özyazıcı, M.A., Korkmaz, A., Gülsar, C. 1995. Samsun Yöresinde Yalnız ve Adi Fiğ İle Karışık Yetiştirilen Bazı Yulaf Çeşitlerinden Elde Edilen Kuru Otun Mineral Madde Kompozisyonu, O.M.Ü. Ziraat Fakültesi Dergisi. 10 (3): 119-132.

Bağcı, A., Geçgel, Ü., Özcan, M. M., Dumlupınar, Z., Uslu, N. 2019. Oil contents and fatty acid composition of oat (Avena sativa L.) seed and oils. Journal of Agroalimentary Processes and Technologies, 25 (4), 182-186.

Bityutskii, N. P., Loskutov, I., Yakkonen, K., Konarev, A., Shelenga, T., Khoreva, V., Blinova, E., Ryumin, A. 2020. Screening of Avena sativa cultivars for iron, zinc, manganese, protein and oil content and fatty acid composition in whole grains. Cereal Research Communications, 48, 87-94. doi: 10.1007/s42976-019-00002-2

Brunava L., Alsina I., Zute S., Sterna V., Vicupe Z. 2014. Some chemical yield and quality properties of domestic oat cultivars. In 9th Baltic Conference on Food science and Technology "Food for Consumer Well-being" FOODBALT 2014, Jelgava, Latvia, p. 72-76.

Carlson, M. O., Montilla-Bascon, G., Hoekenga, O. A., Tinker, N. A., Poland, J., Baseggio, M., Yeats, T. H. 2019. Multivariate genome-wide association analyses reveal the genetic basis of seed fatty acid composition in oat (Avena sativa L.). G3: Genes, Genomes, Genetics, 9(9), 2963-2975. doi: 10.1534/g3.119.400228

de Oliveira Maximino, J. V., Barros, L. M., Pereira, R. M., de Santi, I. I., Aranha, B. C., Busanello, C., Pegoraro, C. 2020. Mineral and fatty acid content variation in white oat genotypes grown in Brazil. Biological Trace Element Research, 1-13. doi:10.1007/s12011-020-02229-1

Doehlert, D. C., Mcmullen M. S., Hammond J. J. 2001. Genotyping and environmental effects on grain yield and quality of oat grown in North Dakota. Crop Sci., 41, 1066-1072. doi: 10.2135/cropsci2001.4141066x.

FAO, 2018. Food and Agriculture Organization of the United Nations Statistics (FAOSTAT) Food and Agriculture Data. http://www.fao.org/faostat/en/?\#home (erişim tarihi: 18.06.2020)

Grundy, M.M.L., Fardet, A., Tosh, S. M., Rich, G. T., Wilde, P. J. 2018. Processing of oat: the impact on oat's cholesterol lowering effect. Food Funct. 9: 1328-1343. doi:10.1039/C7FO02006F.

Hawerroth, M.C., Carvalho, F.I.F., De Oliveira, A.C., De Silva, J.A.G., Da Gutkoski, L.C., Sartori, J.F., Woyann, L.G., Barbieri, R.L., Hawerroth, F.J. 2013. Adaptability and stability of white oat cultivars in relation to chemical composition of the caryopsis. Pesqui. Agropecuária Bras., 48, 42-50. doi:10.1590/S0100204 X2013000100006.

Hoffmann L.A. 1995. World production and use of oats, In: Welch, R.W., (ed.), The Oat Crop-Production and Utilization. Chapman and Hall, London, pp. 34-61.

Li, X. P., Li, M. Y., Ling, A. J., Hu, X. Z., Ma, Z., Liu, L., Li, Y. X. 2017. Effects of genotype and environment on avenanthramides and antioxidant activity of oats grown in northwestern China. Journal of Cereal Science, 73, 130-137.

Martinez, M. F., Arelovish, H. M., Wehrhahne, L. N. 2010. Grain yield, nutrient content and lipid profile of oat genotypes grown in a semiarid environment. Field Crops Research, 116, 92-100.

Meydani, M. 2009. Potential health benefits of avenanthramides of oats. Nutr. Rev., 67, 731-735. doi: 10.1111/j.1753-4887.2009.00256.x

Michels, D. K., Chatham, L. A., Butts-Wilmsmeyer, C. J., Juvik, J. A., Kolb, F. L. 2020. Variation in avenanthramide content in spring oat over multiple environments. Journal of Cereal Science, 91, 102886.

Mut, Z., Erbaş Köse, Ö.D., Akay, H. 2016. Grain yield and some quality traits of different oat (Avena sativa L.) genotypes. International Journal of Environmental \& Agriculture Research, 2 (12),83-88.

Mut, Z., Erbaş Köse, Ö.D., Akay, H. 2017. Chemical quality properties of different oat (Avena sativa L.) cultivars. Yuzuncu Y1l University Journal of Agricultural Sciences, 27 (3), 347-356. doi:10.29133/yyutbd.290920

Mut, Z., Akay, H., Erbaş Köse, Ö.D. (2018). Grain yield, quality traits and grain yield stability of local oat cultivars. Journal of Soil Science and Plant Nutrition, 18(1), 269-281. https://doi.org/10.4067/S0718-95162018005001001

National Research Council, 2001. Nutrient requirements of dairy cattle. 7th revised ed. National Academy Press, Washington, DC, USA.

O'fallon, J. V., Busboom J. R., Nelson, M. L., Gaskins, C. T. 2007. A direct method for fatty acid methyl ester synthesis: application to wet meat tissues, oils, and feedstuffs. Journal of Animal Science, 85(6), 1511-1521. https://doi.org/10.2527/jas.2006-491

Peterson, D. M., Wesenberg, D. M., Burrup D. E., Erickson C.A. 2005. Relationships among agronomic traits and grain composition in oat genotypes grown in different environments. Crop Sciences, 45, 1249-1255. https://doi.org/10.2135/cropsci2004.0063 
Punia, S., Sandhu, K. S., Dhull, S. G., Siroha, A. K., Purewal, S. S., Kaur, M., Kidwai, M. K. 2020. Oat starch: Physico-chemical, morphological, rheological characteristics and its application-A review. International Journal of Biological Macromolecules. 154, 493-498

Rauf, M., Yoon, H., Lee, S., Shin, M. J., Ko, H. C., Lee, M. C., Choi, Y. M. 2019. Evaluation of major dietary ingredients in diverse oats (Avena sativa L.) germplasm. Journal of Crop Science and Biotechnology, 22(5), 495507. https://doi.org/10.1007/s12892-019-0274-0

Silveira, S.F.S., Oliveira, D.C.S., Wolter, D.D., Luche, H.S., de Oliveira, V.F., Figueiredo, R. 2016. Performance of white oat cultivars for grain chemical content. Can. J. Plant Sci., 96, 530-538. doi: 10.1139/cjps-2015-0145.

Tamm, I. 2003. Genetic and environmental variation of grain yield of oat varietes. Agronomy Research, 1(1), 93-97.

Tiwari, U., Cummins, E. 2009. Simulation of the factors affecting $\beta$-glucan levels during the cultivation of oats. Journal of Cereal Science, 50(2), 175-183.

Valentine, J., Cowan, A. A., Marshall, A. H. 2011. Oat Breeding, pp. 11-30 in Oats: Chemistry and Technology, edited by Webster, F. H., and P. J. Wood. AACC International, Inc., St. Paul, Minnesota. doi:/10.1094/9781891127649.002

Van Dyke, N.J., Anderson, P. M. 2000. Interpreting a forage analysis. Alabama cooperative extension. Circular ANR-890.

Van Soest, P. J., Robertson, J. B., Lewis, B. A. 1991. Methods for dietary Fiber, neutral detergent fiber, and nonstarch polysaccharides in relation to animal nutrition. Journal of Dairy Science, 74(10), 3583-3597. https://doi.org/10.3168/jds.S0022-0302(91)78551-2. 